\title{
O CAMPONÊS E SEU CORPO 1
}

\author{
Pierre Bourdieu
}

RESUMO

Baseado em um estudo da cidade em que passou a infância (no Béarn, no Sudoeste da França), realizado nos anos 1960, combinando história, estatística e etnografia, o autor demonstra como as posições econômicas e sociais influenciam no crescimento da taxa de celibato em uma sociedade camponesa baseada na primogenitura graças à mediação da consciência incorporada que os homens adquirem de sua posição social. A cena de um baile local em que os solteiros reúnem-se à parte serve para iluminar e dissecar o choque cultural entre o campo e a cidade e a conseqüente desvalorização dos jovens do campo quando as categorias urbanas de julgamento penetram no mundo rural. Como sua educação e sua posição social leva as jovens a serem sensiveis à "apresentação" (aparência, vestimenta, porte, comportamento), bem como abertas aos ideais urbanos, elas assimilam os padrões culturais vindos da cidade mais rapidamente que os rapazes, o que condena os últimos a serem medidos por metros que os desvalorizam aos olhos de suas potenciais cônjuges. Como o camponês internaliza, por seu turno, a imagem desvalorizada que os outros formam de si a partir das categorias urbanas, ele passa a perceber seu próprio corpo como um corpo "encamponizado" ["em-peasanted"], carregado dos traços das atividades e das atitudes associadas à vida rural. A má consciência que ele tem de seu corpo leva-o a romper a comunhão com ele e a adotar uma atitude introvertida que amplifica a vergonha e o sem-jeito produzidos pelas relações sociais marcadas pela extrema segregação dos sexos e pela repressão do compartilhamento das emoções.

PALAVRAS-CHAVE: celibato; casamento; campesinato; habitus; cultura local; relações de gênero; Béarn.

Em suas leis, Platão considera que não há no mundo calamidade pior para a cidade que dar liberdade à juventude para modificar a forma dos trajes, dos gestos, das danças, dos exercícios e das canções.

Montaigne, Ensaios, I, xliii.

Se os dados da estatística e da observação autorizam estabelecer uma estreita correlação entre a tendência para permanecer solteiro e a residência nos hameaux ${ }^{2}$; se a perspectiva histórica

\footnotetext{
1 Tradução: Luciano Codato. Revisão: Fábia Berlatto e Bruna Gisi. No original: Le paysan et son corps, presente em Bourdieu, 2002, p. 110-129. A tradução para o inglês, de Loïc Wacquant e Richard Nice, foi utilizada para cotejo com o texto original e como fonte das notas da presente versão (cf. BOURDIEU, 2004, p. 579-598). As notas de rodapé sem indicação são de autoria do próprio Pierre Bourdieu. Outra versão do artigo foi anteriormente publicada sob o título Célibat et condition paysanne [Celibato e condição camponesa] (BOURDIEU, 1962a, p. 32136). Revisão final: Adriano Codato.

2 Pequenos agrupamentos de casas de fazenda na zona rural francesa, em torno de um bourg, isto é, de uma cidadezinha ou vilarejo, que o autor menciona logo a seguir (nota de L. Wacquant).
}

Recebido em 25 de outubro de 2005 Aprovado em 19 de novembro de 2005 permite considerar, com base na oposição entre o bourg e os hameaux, a reestruturação do sistema de trocas matrimoniais como uma manifestação da transformação global da sociedade; então resta determinar se um aspecto dessa oposição é que estaria em uma correlação mais estreita com a tendência para permanecer solteiro, e por quais mediações o fato de residir no bourg ou nos hameaux, bem como as características econômicas, sociais e psicológicas vinculadas a esse fato, pode atuar no mecanismo das trocas matrimoniais; resta determinar como a influência da residência pode não se exercer da mesma forma sobre os homens e as mulheres, e se existem diferenças significativas entre as pessoas do hameau que se casam e as condenadas a permanecer solteiras; enfim, resta determinar se o fato de ter nascido no bourg ou no hameau é "condição necessitante" ou "condição permissiva" do celibato.

Rev. Sociol. Polít., Curitiba, 26, p. 83-92, jun. 2006 
Na sociedade antiga, o casamento era, sobretudo, assunto da família, ao passo que hoje a busca do parceiro é, como se sabe, reservada à iniciativa do indivíduo. O que se trata de compreender melhor é por que o camponês dos hameaux é intrinsecamente desfavorecido nessa competição e, mais precisamente, por que se mostra tão mal adaptado, tão desconcertado, nas ocasiões institucionalizadas de encontro entre os sexos.

Em virtude da separação radical entre a sociedade masculina e a sociedade feminina, em virtude do desaparecimento dos intermediadores e do afrouxamento dos laços sociais tradicionais, os bailes que periodicamente se realizam no bourg ou nos vilarejos vizinhos se tornaram a única ocasião socialmente aprovada de encontro entre os sexos $^{3}$. Em conseqüência, esses bailes oferecem uma ocasião privilegiada para se compreender a raiz das tensões e dos conflitos.

$\mathrm{O}$ baile de Natal é realizado em um salão nos fundos de um café. No meio da pista, uma dezena de casais dança, com muita facilidade, os ritmos da moda. São principalmente os "estudantes" (lous estudians), isto é, os alunos do curso secundário e dos colégios dos vilarejos vizinhos, a maioria proveniente do bourg. Há também alguns páraquedistas seguros de si e alguns jovens da cidade, operários ou empregados; dentre eles, dois ou três usam chapéu tirolês e se vestem com jeans azul e jaqueta de couro preta. Dentre as jovens na pista de dança, várias vêm dos recônditos dos hameaux mais distantes, vestidas e penteadas com elegância, às vezes de maneira estudada; outras são de Lesquire $^{4}$, trabalham em Pau ou Paris como costureiras, empregadas domésticas ou vendedoras. Todas têm a aparência de moça da cidade. Algumas jovens, mesmo meninas de doze anos, dançam entre si, enquanto os rapazes andam uns atrás dos outros e se empurram em meio aos casais que dançam.

Em volta da pista, um grupo de espectadores, mais velhos, observa em silêncio, formando uma

\footnotetext{
3 Para um exame mais completo da estrutura e do funcionamento das relações de gênero, por volta do mesmo período, na região de Béarn, cf. BOURDIEU, 1962b, p. $307-$ 331 (nota de L. Wacquant).

4 A cidadezinha a que Bourdieu refere-se pelo nome de Lesquire é, na realidade, Lasseube, onde o autor cresceu (nota de L. Wacquant).
}

massa sombria. Aos poucos eles avançam, como se tomados pela tentação de dançar, reduzindo o espaço destinado aos casais. Nessa massa estão todos os solteiros. Os homens dessa idade já casados não vão mais a bailes. Só vão ao baile na época da feira agrícola, o grande festival da cidade. Nesse dia, todo mundo "vai passear" e todos, até os "velhos", dançam. Só os solteiros não dançam. Eles não se fazem notar tanto nessas noites do festival porque todos os homens e mulheres da cidade vão à feira, uns para conversar com os amigos, outros para dar uma espiada, fofocar e fazer mil conjecturas sobre os possíveis casamentos. Mas nos bailes menores, como no Natal ou no Ano Novo, os solteiros não têm nada para fazer. Esses são bailes a que se vai para dançar, os solteiros não dançarão e sabem disso. São bailes feitos para os jovens, ou seja, para quem não é casado. Embora não estejam mais na idade, os solteiros são "incasáveis" e sabem que o são. De vez em quando, como que para dissimular o desconforto, eles brincam um pouco. Som de "marcha", nova dança: uma jovem vai até o canto dos solteiros e tenta carregar um deles para a pista. Ele resiste, constrangido, mas contente. Dança uma música só, exagerando, de propósito, a inabilidade e o peso de seus pés, um pouco à maneira dos idosos quando dançam no festival; ele fica olhando para trás, rindo para seus companheiros. A dança termina, senta-se e não dançará mais. "Aquele", uma pessoa me diz, "é o fillho de fulano (um grande proprietário); a jovem que veio tirá-lo para dançar é uma vizinha. Ela fez isso para animálo." Tudo volta ao normal. Os solteiros ficarão até meia-noite, quase sem falar nada, sob a luz e o rebuliço do baile, com os olhos nas jovens inacessíveis. Depois vão à sala do café beber juntos. Alguns entoarão, com toda a voz, velhas canções da região de Béarn, prolongando os acordes dissonantes até perder o fôlego, enquanto a orquestra, no salão vizinho, toca twist e tcha-tchatcha. Mais tarde, os solteiros voltarão bem devagar, em pequenos grupos, para suas fazendas distantes do vilarejo.

Na sala do café, três solteiros, sentados à mesa, bebem e conversam:

“- Então, você não dança?”

“- Não, dançar já não é mais para nós...”

Um morador da cidadezinha, que estava comigo, se intromete: 
“-Até parece! Eles nunca dançaram!”

Outro solteiro:

"- Espero até meia-noite. Acabei de dar uma olhada, só há jovens. Elas não são para mim. Essas moças poderiam ser minhas filhas... Vou comer alguma coisa e volto já. Aliás, já não tenho mais idade para dançar. Uma bela valsa eu dançaria, mas eles não tocam. $\mathrm{E}$ as moças não sabem dançar valsa."

"- Você acha que as moças mais velhas ainda vêm esta noite?”

“- Vamos ver. E você, por que não está dançando?"

“- Se tivesse uma esposa, estaria dançando, pode ter certeza."

Fala o morador que estava comigo:

“- Se eles dançassem, teriam uma esposa. Não tem saída."

Outro solteiro:

“- Ah! Não precisa se preocupar com a gente. Não somos infelizes!"

Ao final do baile, dois solteiros saem lentamente. Um carro dá partida, eles ficam esperando. $\mathrm{O}$ morador me diz:

“- Está vendo? Eles olham para esse carro como estavam olhando para as moças a pouco. Pode ter certeza, eles não estão com pressa... Ainda vão andar por aí o quanto puderem."

Esse pequeno baile do interior dá ocasião a um verdadeiro choque de civilizações. Nele é todo o mundo da cidade, com seus modelos culturais, sua música, suas danças, suas técnicas corporais, que irrompe na vida camponesa. Os modelos tradicionais dos comportamentos em festas se perderam ou deram lugar a modelos urbanos. Nesse domínio, como em outros, a iniciativa é das pessoas do bourg. As danças de antigamente, que traziam a marca do campo em seus nomes (la crabe, lou branlou, lou mounchicou etc.), em seus ritmos, em sua música, nas letras das músicas, foram substituídas por danças importadas da cidade. A propósito, é preciso admitir que as técnicas corporais constituem verdadeiros sistemas, solidários a todo um contexto cultural. Aqui não é o caso de analisar os hábitos motores característicos do camponês de Béarn, esse habitus que denuncia o paysanás, o camponês "pesadão". A observação popular apreende perfeitamente essa hexis, que serve de fundamento aos estereótipos. "Os camponeses de antigamente", dizia um idoso da cidadezinha, "andavam sempre com as pernas arqueadas, como se tivessem os joelhos virados para dentro, com os braços curvados" 5 . Para explicar essa atitude, ele alude à postura do ceifeiro. A observação crítica dos moradores da cidade, hábeis para perceber o habitus do camponês como uma verdadeira unidade sintética, dá ênfase à lentidão e ao peso do andar; o homem da brane [região das montanhas] é, para o habitante do bourg, aquele que sempre caminha em um solo irregular, acidentado e lamacento, mesmo quando anda no asfalto da carrère [rua principal]; é aquele que arrasta galochas enormes ou botas pesadas, mesmo calçando seus sapatos de domingo; é quem sempre avança com passos lentos e largos, como quando anda com uma vara no ombro, virandose às vezes para chamar o gado que o segue. Sem dúvida, não se trata de uma descrição verdadeiramente antropológica (PELOSSE, 1956); mas, por um lado, essa etnografia espontânea dos moradores da cidade apreende as técnicas corporais como elemento de um sistema e postula implicitamente a existência de uma correlação, no nível do sentido, entre o peso do andar, o mau corte da roupa e a falta de jeito na expressão; por outro lado, essa etnografia indica que é, sem dúvida, no nível dos ritmos que se encontraria o princípio unificador (apreendido de maneira confusa pela intuição) do sistema das atitudes corporais características do camponês. Para quem se lembra da anedota de Mauss sobre as desventuras de um regimento britânico marchando ao som de uma fanfarra francesa, é claro que o camponês empaysanit, ou seja, o camponês "rústico"6, não fica à vontade no baile (MAUSS, 1973, p. 366). De fato, assim como as danças de antigamente eram solidárias a toda uma civilização camponesa ${ }^{7}$, as danças modernas são

5 P. L.-M.: 88 anos, natural de Lesquire; residente no bourg; solteiro; educação: nível primário; entrevistas em francês e bearnês.

6 No original: "empaysanné". A tradução literal seria "camponeizado". Optou-se pelo adjetivo "rústico" devido a seu sentido etimológico ("rural", "campestre") e a seu sentido figurado ("rude", "grosseiro", "inculto", "incivil") (N. T.).

7 O esporte oferece outra ocasião para se verificarem essas análises. Na equipe de rúgbi, esporte urbano, encontram-se quase exclusivamente os "citadinos" do bourg. Também 
solidárias à civilização urbana; elas exigem a adoção de novas atitudes corporais, demandam uma verdadeira mudança de "natureza", dado que o habitus corporal consiste naquilo que se vive como mais natural, aquilo sobre o que a ação consciente não tem controle. Pensem nas danças como o charleston ou o tcha-tcha-tcha, em que os parceiros ficam frente a frente, dão pulinhos em ritmo de semitons, sem jamais chegarem a se abraçar $^{8}$. Pode haver algo mais estranho ao camponês? O que ele faria com suas mãos enormes, que costuma deixar largadas, longe do corpo? De resto, a mera observação e as entrevistas dão testemunho de que o camponês sofre para adotar os ritmos da dança moderna.

Ba. dançou um pouco java e dois pra lá, dois pra cá. Ele costumava se adiantar um tanto à orquestra. Para ele, nada de músicas de dois, três ou quatro tempos. Ia em frente, pisava no pé dos outros ou coisa pior, mas o que importava era a velocidade. Ele foi logo relegado à condição de espectador e nunca escondeu seu despeito por jamais ter sido capaz de dançar de forma conveniente ${ }^{9}$.

$66 \%$ dos solteiros não sabem dançar (contra $20 \%$ dos casados); apesar disso, um terço dos solteiros vai aos bailes.

nesse caso, como no baile, os "estudantes" e os carrèrens [moradores da cidadezinha] são preparados, por todo seu aprendizado cultural, a participar de um jogo que exige não apenas força, mas também destreza, astúcia, elegância. Ao assistirem às partidas desde a primeira infância, eles têm noção do jogo antes mesmo de jogá-lo. Os jogos que antigamente se realizavam nas festas (lou die de Nouste-Dame, em 15 de agosto, festa do padroeiro da vila), lous sauts (os saltos), lou jete-barres (o lançamento de barras), a corrida, o boliche, exigiam, antes de mais nada, qualidades atléticas, dando aos camponeses oportunidade para mostrar seu vigor.

8 Curt Sachs (Weltgeschichte des Tanzes, Berlin, 1933, citado por Mauss (1973, p. 380)) opõe as sociedades feminilizadas, em que se costuma dançar requebrando, no mesmo local, às sociedades cuja precedência é masculina, em que se teria prazer no deslocamento. Pode-se arriscar a sugerir que tal aversão à dança, apresentada por muitos jovens camponeses, poderia explicar-se por sua resistência a uma espécie de "afeminação" de toda uma imagem profundamente arraigada de si e de seu corpo.

9 P. C.: 32 anos, natural de Lesquire; residente no bourg; casado; educação: nível secundário; pequeno empresário; entrevistas em francês e, em alguns momentos, em bearnês.
Além disso, a "aparência" ("la tenue”) é imediatamente percebida, em particular pelas jovens, como símbolo da condição econômica e social. De fato, a hexis corporal é, antes de tudo, signum social $^{10}$. Talvez isso seja verdadeiro particularmente no que se refere ao camponês. Aquilo que se denomina "jeito camponês" é, sem dúvida, o resíduo irredutível de que mesmo aqueles camponeses mais abertos ao mundo moderno, isto é, mais dinâmicos e inovadores em sua atividade profissional, não chegam a se livrar ${ }^{11}$.

Ora, nas relações entre os sexos, o primeiro objeto da percepção é a hexis corporal como um todo, em si mesma e, ao mesmo tempo, a título de signum social. Por menos desajeitado, mal barbeado, mal vestido que seja, o camponês é imediatamente percebido como hucou (coruja), pouco sociável e grosseiro, "sombrio (escu), desajeitado (desestruc), carrancudo (arrebouhiec), às vezes grosso (a cops groussè), pouco amável com as mulheres (chic amistous dap las hennes)" (P. L.M.). Dele se diz o seguinte: n'ey pas de hère, ou seja, ao pé da letra, "ele não é de feira" (para ir ao festival, vestia-se o que se tinha de melhor), ele não é bem apresentável. Assim, particularmente atentas e sensíveis, devido a toda sua formação cultural, aos gestos e atitudes, aos trajes e ao conjunto do comportamento (tenue), prontas para deduzir a personalidade profunda a partir da aparência (apparence) exterior, as moças, mais abertas aos ideais da cidade, julgam os homens segundo critérios que lhes são alheios; avaliados segundo esse padrão, eles são desvalorizados.

\footnotetext{
10 Eis por que, em vez de esboçar uma análise metódica das técnicas corporais, pareceu preferível registrar a imagem que os moradores da cidade fazem do camponês e que, para o bem ou para o mal, ele tende a introjetar.

11 Toda uma categoria de solteiros corresponde a essa descrição. "Ba. é um rapaz inteligente, com um físico atlético, soube modernizar sua fazenda, que tem uma bela propriedade. Mas jamais soube dançar de forma conveniente (cf. acima, no corpo do texto, outra declaração de P. C. sobre Ba.). Ele sempre se pôs a observar os outros, como em uma noite dessas, até duas da manhã. É o caso típico do rapaz a quem faltaram oportunidades para se aproximar das moças. Nada o impediria de encontrar uma esposa: nem sua inteligência, nem sua condição financeira, nem seu físico" (P. C.). "Co. dançava de forma conveniente, mas sem que jamais tivesse podido - $\mathrm{e}$ isso apenas por sua classe - fazer um convite a outras moças, senão às camponesas, para uma dança" (P. C.). Cf. a seguir, no corpo do texto, as declarações de P. C. sobre o caso de Pi.
} 
Em tal situação, o camponês é levado a introjetar a imagem que os outros fazem dele, mesmo quando se trata de um mero estereótipo. Passa a perceber seu corpo como corpo cunhado pela impressão social, como corpo empaysanit, rude, carregando o traço das atitudes e atividades associadas à vida camponesa. Em conseqüência, fica embaraçado em relação a seu corpo e em seu corpo. É por apreender seu corpo como corpo de camponês que tem dele uma consciência infeliz. É por apreender seu corpo como corpo rude que toma consciência de ser camponês rústico. Não é exagero presumir que a tomada de consciência de seu corpo é, para o camponês, a ocasião privilegiada da tomada de consciência da condição camponesa.

Essa consciência infeliz de seu corpo, que leva o camponês a deixar de se solidarizar com seu corpo (diferentemente do morador da cidade), que inclina o camponês a uma atitude introvertida, raiz da timidez e do enviezamento (gaucherie), impede-o de dançar, de ter atitudes simples e naturais na presença das moças. De fato, embaraçado em relação a seu corpo, ele fica desconfortável e sem jeito em todas as situações que demandam extroversão e nas quais seu corpo é posto em cena. Pôr o corpo em cena, como na dança, supõe que se admita exteriorizar-se e que se tenha uma consciência satisfeita da imagem que se passa para os outros. Ao contrário, o temor do ridículo e a timidez estão ligados a uma consciência penetrante de si mesmo e de seu corpo, a uma consciência fascinada pelo estado físico. Assim, tal aversão à dança nada mais é que uma manifestação dessa consciência penetrante da condição camponesa, que também se exprime, como já se viu, no riso e na ironia em relação a si mesmo; especialmente nas histórias jocosas cujo anti-herói é sempre o camponês confrontado com o mundo da cidade.

Portanto, a condição econômica e social influi na tendência para o casamento, principalmente por meio da consciência que os homens adquirem dessa situação. De fato, o camponês que toma consciência de si tem boas chances de se apreender como camponês no sentido pejorativo. Podese verificar isso no fato de que se distinguem, dentre os solteiros, os camponeses mais rústicos e os mais conscientes, aqueles mais conscientes do que neles resta de camponês ${ }^{12}$.

12 Muitos rapazes do bourg são, de fato, tão grosseiros
É natural que o encontro do camponês com uma jovem leve esse mal-estar ao paroxismo. Primeiro porque, para o camponês, é a ocasião em que se experimenta, mais intensamente que nunca, o embaraço em relação a seu próprio corpo. Além disso, em virtude da separação entre os sexos, uma jovem é toda cercada de mistério.

Pi. participou das excursões organizadas pelo vigário da paróquia. Quase não iam à praia por causa dos maiôs, provocantes. Eram excursões mistas, com as moças do mesmo movimento, a JAC ${ }^{13}$. Esses passeios, muito raros, um ou dois por ano, são feitos antes do serviço militar. Nessas excursões, as moças só ficavam entre si, fechadas em sua roda. Apesar de cantarem juntos algumas vezes e participarem de algumas brincadeiras tímidas, tem-se a impressão de que nada pode acontecer entre os participantes. No campo não existe amizade entre as moças e os rapazes. Só se pode ser amigo de uma moça quando já se teve uma amizade e se sabe o que seja isso. Para a maioria dos rapazes, uma moça é uma moça, com tudo aquilo que as moças têm de misterioso, com essa enorme separação entre os sexos e um fosso difícil de transpor. Uma das melhores maneiras de se aproximar das mulheres, a única maneira no campo, é o baile. Depois de algumas tímidas tentativas, de um aprendizado que não o levou a dançar nada além de java, Pi. não insistiu mais. Eles vão atrás de uma vizinha, alguém que não se atreve a recusar ao menos uma dança. Dançar uma ou duas vezes por baile, ou seja, de quinze em quinze dias ou de mês em mês é pouco, muito pouco. Com certeza, é pouco demais para que se possa ir a bailes mais distantes com alguma chance de sucesso. É assim que se vira um desses que fica olhando os outros dançar. Fica-se olhando os casais até duas da manhã; depois se volta para casa pensando que esses casais se divertem bastante; é assim que se aprofunda o fosso. Quando se tem como projeto se casar, a situação fica grave. Como se aproximar de uma moça que o agrada? Como achar a oportunidade, sobretudo quando não se é um "atirado"? Só no baile. Fora do baile, sem chance... Como puxar uma conversa e levá-la para um assunto embaraçoso? Mil vezes melhor dançando um tango... A falta de relações e de

quanto certos camponeses dos hameaux, mas não têm consciência disso.

13 "Jeunesse Agricole Catholique", movimento dos jovens católicos camponeses, fundado em 1929, atuante na região de Béarn nos anos 1960 (nota de L. Wacquant). 
contatos com o sexo oposto termina criando complexos, mesmo naquele camponês mais ousado. A coisa fica mais grave ainda quando o indivíduo é um pouco tímido por natureza. A timidez pode ser superada quando se tem contato permanente com as mulheres, caso contrário ela pode se agravar. $\mathrm{O}$ medo de parecer ridículo, uma forma de orgulho, também pode inibir. A timidez, às vezes um pouco de falso brio, o fato de sair de um buraco, tudo isso aprofunda o fosso entre uma moça e um rapaz de valor" (P. C.).

As normas culturais que regem a expressão dos sentimentos contribuem para dificultar o diálogo. Por exemplo, o afeto entre pais e crianças exprime-se muito mais por atitudes e gestos concretos que por palavras. "Antigamente, quando ainda se colhia com foice, os ceifeiros avançavam em fileiras. Meu pai, que trabalhava ao meu lado, quando via que eu estava exausto, colhia na minha frente, sem dizer nada, para me aliviar"14. Não faz muito tempo, pai e filho passavam por certo desconforto ao se verem juntos em um café, sem dúvida porque podia ser o caso de alguém contar histórias despudoradas na presença deles ou de tocar em assuntos licenciosos, o que causava, em ambos, um desconforto insuportável. O mesmo pudor dominava as relações entre irmãos e irmãs. Tudo que é da ordem da intimidade, da "natureza", é banido das conversas. Mesmo que o camponês goste de contar ou de ouvir as anedotas mais picantes, ele é extremamente discreto em relação a sua própria vida sexual e, sobretudo, afetiva.

De maneira geral, os sentimentos não são temas sobre os quais o camponês fica à vontade para falar. A inabilidade verbal, que vem se juntar à inabilidade corporal, é vivenciada no desconforto tanto do rapaz como da moça, sobretudo quando ela aprendeu, nas revistas femininas e nos romances de folhetim, a linguagem estereotipada do sentimentalismo da cidade.

Para dançar não basta saber os passos, colocar um pé na frente do outro. Até isso, para alguns, não é tão fácil. Também é preciso saber conversar um pouco durante a dança e depois. Enquanto se dança, é preciso ser capaz de falar de outra coisa além dos trabalhos agrícolas ou do tempo. E não

14 A.B.: 60 anos, natural de Lesquire; residente no bourg; casado; educação: nível secundário; entrevistas em francês e, em alguns momentos, em bearnês. são muitos que são capazes disso"15.

Se as mulheres são muito mais aptas e mais dispostas que os homens para adotar os modelos culturais urbanos, tanto corporais como indumentários, isso se deve a diversas razões convergentes. Em primeiro lugar, elas são bem mais motivadas para adotar os modelos culturais urbanos que os homens, uma vez que a cidade representa para elas a esperança da emancipação. Em conseqüência, elas dão um exemplo privilegiado daquela "imitação prestigiosa" de que Mauss falava (MAUSS, 1973, p. 369). O atrativo e a influência exercidos pelas novas técnicas e pelos novos produtos em prol do conforto, pelos ideais de civilidade e pelas diversões oferecidas pela cidade, devem-se ao fato, em grande parte, de que neles se reconhece a marca da civilização urbana, identificada, correta ou incorretamente, à civilização. A moda vem de Paris, da cidade, o modelo se impõe de cima. As mulheres aspiram fortemente à vida citadina e essa aspiração não é sem razão, pois, segundo a própria lógica das trocas matrimoniais, as mulheres circulam de baixo para cima. Portanto, é do casamento, antes de mais nada, que elas esperam a realização de suas expectativas. Ao porem todas as esperanças no casamento, elas são fortemente motivadas para se adaptar, adotando a aparência da mulher urbana.

Além disso, as mulheres são preparadas, por toda sua formação cultural, para estar atentas aos detalhes exteriores da pessoa e, mais particularmente, de tudo que se refere à "apresentação" (tenue), nos diferentes sentidos do termo. Elas têm, como que de maneira estatutária, o monopólio do juízo de gosto. Essa atitude é encorajada e favorecida por todo o sistema cultural. Não é difícil ver uma menina de dez anos discutir com sua mãe ou suas amigas o corte de uma saia ou de uma blusa. Esse tipo de comportamento é rejeitado pelos rapazes, na medida em que é desencorajado mediante sanção social. Em uma sociedade dominada pelos valores masculinos, tudo contribui, em contrapartida, para favorecer a postura tosca e grosseira, rude e belicosa. Um homem muito atento a seus trajes, a sua aparência (tenue), seria considerado muito

15 R.L.: 35 anos, natural de Lesquire; residente em um hameau; casado; sabe ler e escrever; comerciante; entrevistas em francês. 
“encavalheirado", ou ainda, o que dá na mesma, muito afeminado. Em conseqüência, enquanto os homens são, em virtude das normas que regem sua primeira educação, acometidos por uma espécie de cegueira cultural (no sentido em que os lingüistas falam em "surdez cultural"16) no que se refere à "apresentação" (tenue) como um todo, da hexis corporal à cosmética, as mulheres são muito mais aptas para perceber e integrar modelos urbanos em seu comportamento, tanto no que se refere ao vestuário como à técnica corporal ${ }^{17}$. A camponesa fala bem a língua da moda urbana porque a entende bem, e a entende bem porque a "estrutura" de sua língua cultural a predispõe para isso. $\mathrm{O}$ que os camponeses e as camponesas percebem, tanto no morador da cidade e no mundo da cidade como também nos outros camponeses, é pois em razão de seus respectivos sistemas culturais. Daí decorre que, enquanto as mulheres adotam inicialmente os signos exteriores da "urbanidade", os homens tomam emprestados modelos culturais mais profundos, em particular nos domínios técnico e econômico. Também é compreensível que seja assim. A cidade é, para a camponesa, antes de tudo a grande loja de departamentos. Mesmo que algumas dessas lojas se destinem, de fato, a uma minoria, grande parte delas se dirige a todas as classes. "Quanto ao vestuário", observa Halbwachs, "todo mundo faz uso dele na rua e as pessoas de todas as classes se observam, se comparam, embora tenda a se estabelecer uma certa uniformidade em relação a ele. Há uma unidade no mercado de alimentação e, em certa medida, também no mercado de vestuário" (HALBWACHS, 1955, p. 174). Devido ao caráter unilateral e superficial de sua percepção da cida-

16 PULGRAM (1959) fala em "cultural deaf-muteness" [surdo-mudez cultural]. Cf. também TROUBETZKOY (1964, p. 55-56; p. 66-67).

17 O vestuário é um aspecto importante do comportamento em geral. É nesse domínio que se revela melhor a "cegueira cultural" dos homens em relação a certos aspectos da civilização urbana. A maioria dos solteiros veste a roupa confeccionada pelo alfaiate da cidadezinha. "Alguns tentam vestir conjuntos esporte. Eles se atrapalham na combinação das cores. Na família, só quando a mãe é atualizada ou, melhor ainda, quando as irmãs - mais abertas à moda - se ocupam da questão, é que se vêem camponeses bem vestidos" (P. C.) De maneira geral, o fato de ter irmãs só pode aumentar as chances de casamento para um rapaz. Por meio delas, pode-se conhecer outras moças; ocorre também de ser possível aprender a dançar com elas. de, é normal que a jovem camponesa associe à vida urbana certos tipos de roupas e de penteados, signos manifestos, a seus olhos, de libertação. Em resumo, ela não vê senão, como se diz, o lado bom da cidade. Daí se compreende, por um lado, que a cidade exerça verdadeiro fascínio na jovem camponesa e, por meio da cidade, também os homens citadinos; por outro lado, compreende-se que a jovem camponesa empreste das mulheres da cidade os signos exteriores da condição das citadinas, ou seja, aquilo que conhece dessas mulheres.

Há tempos, para melhor preparar as moças para o casamento - e também porque elas eram menos indispensáveis à fazenda que os rapazes -, muitas famílias orientavam suas filhas para um aprendizado, por exemplo, com uma costureira, assim que elas terminavam a escola. Depois da criação do cours complémentaire ${ }^{18}$, elas eram levadas mais facilmente que os rapazes a continuar os estudos até o brevet, o que só podia aumentar tanto a atração que a cidade nelas exercia, como o descompasso entre os $\operatorname{sexos}^{19}$. Na cidade, por meio das revistas quinzenais femininas, dos folhetins, das estórias dos filmes, das canções da moda transmitidas pelo rádio ${ }^{20}$, as moças emprestam também os modelos da relação entre os sexos e um tipo de homem ideal, totalmente oposto ao camponês "rústico". Assim se constitui todo um sistema de expectativas que o camponês não poderia preencher. Foi-se o tempo em que a pastorinha não pretendia nada mais que se casar com um "bom filho de camponês" [como se ouvia em uma canção regional21 ${ }^{21}$. Agora se assiste à

18 O cours complémentaire consiste nos anos adicionais da educação depois do ensino primário; já o brevet, mencionado a seguir pelo autor, equivale a um diploma do ensino secundário (nota de L. Wacquant).

19 Divisão dos alunos do cours complémentaire de Lesquire, em 1962, segundo o sexo e a categoria profissional dos pais:

CATEGORIAPROFISSIONAL DOS PAIS

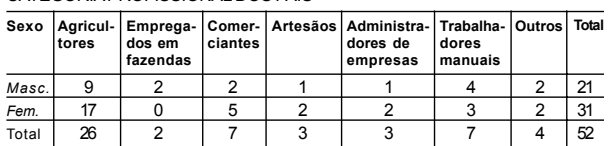

20 Ficando em casa mais tempo que os homens, as mulheres escutavam o rádio muito mais.

21 Na tradução para o inglês, a canção regional, coletada em Lasseube em 1959, é apresentada nos seguintes termos: 
revanche do cavalheiro.

Em virtude da dualidade dos quadros de referência, conseqüência da diferente penetração dos modelos culturais urbanos em ambos os sexos, as mulheres julgam seus conterrâneos camponeses segundo critérios que não lhes dão nenhuma chance. A partir daí, compreende-se que grande número de agricultores modernizados possa ficar solteiro. Nas fazendas dos solteiros, $14 \%$ delas, todas pertencentes a camponeses em boa situação, foram modernizadas. Na nova elite rural, dentre os membros da JAC e, em particular, da $\mathrm{CUMA}^{22}$, muitos deles não são casados. Mesmo que a modernização no domínio da técnica ajude a conferir certo prestígio, ela não necessariamente favorece o casamento.

Rapazes como La., Pi., Po., sem dúvida entre os mais inteligentes e dinâmicos da região, vão entrar no grupo dos "incasáveis". Contudo, eles se vestem corretamente, saem bastante. Introduziram nas fazendas novos métodos, novas culturas. Alguns equiparam suas casas. Deve-se supor que, nessa questão, os imbecis se dão melhor que os outros (P. C.).

Antigamente, o solteiro não era jamais considerado verdadeiramente um adulto pela sociedade, que distinguia claramente as responsabilidades deixadas aos jovens, isto é, aos não-casados, como, por exemplo, a organização das festas, e as responsabilidades reservadas aos adultos, tais como o conselho municipal ${ }^{23}$. Hoje, a condição

"Ballad of the shepherd"

Fair shepherdess, will you give me your love?

I will be forever true to you.

You qu'aymi mey u bet hilh de paysà... (I would rather take a good peasant's son)

Why, shepherdess, are you so cruel?

Et bous moussù qu'et tan amourous? (And you, sir, why are you so amorous?)

I cannot love all those fair ladies...

E you moussù qu'em fouti de bous... (And I, sir, give not a damn for you) (nota de L. Wacquant, a partir da versão publicada em 1962).

22 Coopérative d'utilisation du matériel agricole: cooperativa local, estabelecida em 1956, para aquisição de maquinário agrícola (nota de L. Wacquant).

23 O casamento marca uma ruptura no curso da vida. Do dia para a noite, deixa-se de ir a bailes e acabam as saídas de solteiro aparece cada vez mais como fatalidade, deixando de parecer imputável aos indivíduos, a seus defeitos e imperfeições.

Quando os solteiros são de uma família grande, as pessoas procuram desculpas; sobretudo quando a influência familiar vem se somar à influência de uma personalidade forte. As pessoas dizem: "É uma pena, fulano tem uma bela propriedade, é inteligente etc." Se fulano tem uma personalidade forte, ele termina se impondo, apesar das circunstâncias, caso contrário, ele se vê diminuído (A. B.).

Pode-se ver, de maneira mais concreta, no relato de uma vizinha que foi à fazenda de dois solteiros, um de quarenta anos, outro de trinta e sete, ajudar a pelar um porco.

Dissemos a eles: "Que bagunça!" Essas aves (aquets piocs)! Nada de lavarem a louça! Uma sujeira! Não sabíamos para onde olhar. Colocamos eles para fora e falamos: "Vocês não têm vergonha!? Em vez de se casarem... Nós é que temos que fazer esse trabalho... Falta uma esposa para fazer isso". Eles baixaram a cabeça e saíram. Se há uma daune, mulheres, vizinhas ou parentes, vão lá para ajudá-los. Mas, quando não há esposas, elas têm que resolver tudo (M. P.-B.).

O fato de $42 \%$ das fazendas de solteiros (dos quais $38 \%$ são camponeses pobres) estar em decadência, em comparação com apenas $16 \%$ das fazendas cujos proprietários são casados, mostra uma evidente correlação entre a situação da fazenda e a condição de solteiro. Contudo, a decadência da propriedade pode ser tanto efeito como causa da condição de solteiro. Vivenciada como uma mutilação social, a condição de solteiro determina, em muitos casos, uma postura de resignação e de renúncia, conseqüência da falta de futuro a longo prazo. Pode-se verificar, mais uma vez, em um testemunho:

Fui visitar Mi. na vizinhança de Houratate. Ele tem uma casa de fazenda bem conservada, cercada por pinheiros. Perdeu o pai e a mãe, mais ou menos, em 1954 e, hoje, deve estar com uns 50

noturnas. Já se viram muitos jovens de má fama mudar subitamente de comportamento e, como se diz, "entrar na linha". "Ca. freqüentava todos os bailes. Ele se casou com uma moça mais jovem, que nunca tinha saído. Tiveram três filhos em três anos. Ela nunca sai, apesar de morrer de vontade. Ele nunca pensou em levá-la ao baile ou ao cinema. Tudo isso acabou. Eles nunca vestem uma roupa melhor" (P. C.). 
anos. Vive sozinho. "Estou com vergonha por você me ver deste jeito." Mi. estava assoprando o fogo que tinha feito no pátio para lavar a roupa. "Queria ter te recebido e feito as honras da casa. Afinal, você nunca tinha vindo! Você sabe da desordem total por aqui. Quando se é sozinho... As moças não querem mais vir para o campo. Não tenho mais esperança. Gostaria muito de ter formado uma família. Aumentaria a casa deste lado [é costume aumentar a casa quando se casa o primogênito]. Agora, a terra está arruinada. Não vai haver mais ninguém. Perdi o gosto pelo trabalho na terra. De vez em quando, minha irmã vem para cá. Ela é casada com um funcionário da SNCF [companhia nacional de infra-estrutura em transportes]. Vem com o marido e a filhinha. Mas não pode ficar aqui”"24 (A. B.).

O drama do solteiro é, muitas vezes, redobrado pela pressão da família, desesperada por vê-lo permanecer nessa situação. "Dou bronca neles" diz a mãe de dois filhos, já mais velhos, que ainda não se casaram - "falo assim: Vocês têm medo das mulheres! Vocês passam o tempo todo bebendo! O que vocês vão fazer quando eu não estiver mais aqui? Não posso, eu, cuidar disso para vocês!"25. Outra senhora, dirigindo-se a um amigo de seu filho: "Você precisa lhe dizer para encontrar uma mulher. Ele devia ter se casado ao mesmo tempo em que você! É terrível, pode ter certeza. Estamos sozinhos, nós dois, como dois perdidos" (relatado por P. C.).

Sem dúvida, todo solteiro, por uma questão de honra e de orgulho, procura dissimular o desespero da situação, buscando talvez em uma longa tradição de celibato as fontes da resignação que lhes é indispensável para suportarem uma existência sem presente nem futuro. De todo modo, o celibato é a ocasião privilegiada para se verificar a miséria da condição camponesa. Se o solteiro, para expressar seu infortúnio, diz que "a terra está arruinada", é porque não pode se furtar a compreender sua condição de celibatário como determi-

24 As opiniões das pessoas são quase sempre severas, mas confirmam as conclusões dos próprios solteiros. "Eles não tem gosto pelo trabalho. Há uns cinqüenta nessa situação, eles não se casam. São uns sacos de batata. Se você quiser beber com eles na carrère... A terra está arruinada" (B. P.).

25 Viúva A.: 84 anos, natural de Lesquire; moradora de um hameau; viúva; sabe ler e escrever; proprietária de fazenda; entrevistas em bearnês. nada por uma necessidade que pesa sobre toda a classe camponesa. O celibato dos homens é vivenciado por todos como indício da crise mortal de uma sociedade incapaz de assegurar aos primogênitos, depositários do patrimônio, mesmo aos mais inovadores e mais audaciosos, a possibilidade de perpetuar a linhagem. Em resumo, uma sociedade incapaz de proteger os próprios fundamentos de sua ordem e, ao mesmo tempo, de adaptar-se de maneira inovadora.

\section{CONCLUSÃO}

"As moças não querem mais vir para o campo...”. Os juízos da sociologia espontânea são essencialmente parciais e unilaterais. Sem dúvida, a constituição do objeto de pesquisa, como tal, supõe também a escolha de um aspecto. Mas uma vez que o fato social se dá, seja ele qual for, como pluralidade infinita de aspectos, uma vez que ele aparece como teia de relações a ser desembaraçada uma por uma, essa escolha não pode não se considerar como tal, não pode tomar-se como provisória e ser relegada pela análise de outros aspectos. A tarefa primeira da sociologia é, talvez, a de reconstituir a totalidade a partir da qual se pode descobrir a unidade entre a consciência subjetiva que o indivíduo tem do sistema social e a estrutura objetiva desse sistema. O sociólogo se esforça, de um lado, para recobrar e compreender a consciência espontânea do fato social, consciência que, por essência, não reflete sobre si; e, de outro lado, ele se esforça para apreender o fato em sua própria natureza, graças ao privilégio que lhe confere sua situação de observador que abdica de "agir sobre o social" para pensá-lo. A partir daí, ele se obriga a reconciliar a verdade do dado objetivo, que sua análise lhe permite descobrir, e a certeza subjetiva daqueles que vivem esse dado. Quando o sociólogo descreve, por exemplo, as contradições internas do sistema de trocas matrimoniais, mesmo quando essas contradições não afloram, como tais, à consciência daqueles que são vítimas delas, ele nada mais faz que tematizar a experiência vivida desses homens que concretamente experimentam essas contradições sob a forma da impossibilidade de se casar. Se o sociólogo se proíbe de concordar com a consciência que os sujeitos constroem sobre suas situações e de tomar ao pé da letra a explicação que eles dão a elas, ele considera essa consciência com muita seriedade para tentar descobrir seu fundamento real, só se dando por satisfeito quando consegue abarcar na unidade de uma compreensão a verda- 
de imediatamente dada à consciência vivida e a verdade laboriosamente adquirida pela reflexão científica. A sociologia talvez não merecesse uma hora de esforço se tivesse por finalidade apenas descobrir os cordões que movem os indivíduos que ela observa, se esquecesse que lida com os homens, mesmo quando estes, à maneira das marionetes, jogam um jogo cujas regras ignoram, em suma, se ela não se desse à tarefa de restituir a esses homens o sentido de suas ações.

Pierre Bourdieu ocupou a cadeira de Sociologia no Collège de France, onde dirigiu também o Centro de Sociologia Européia e editou a revista Actes de la recherche en sciences sociales até sua morte em 2002. Ele é autor de vários livros clássicos em Sociologia e Antropologia, incluindo La Reproduction: éléments d'une théorie du système d'enseignement (com Jean-Claude Passeron; 1970), Esquisse d'une theorie de la pratique (1972), La Distinction: critique sociale du jugement (1979), Homo Academicus (1984) e Les règles de l'art: genèse et structure du champ littéraire (1992). Dentre seus estudos etnográficos estão: Le déracinement: la crise de l'agriculture traditionnelle en Algérie (com Adbelmalek Sayad, 1964), Algérie 60: structures économiques et structures temporelles (1977), La misère du monde (1993) e Le Bal des célibataires: crise de la societé em Béarn (2002).

\section{REFERÊNCIAS BIBLIOGRÁFICAS}

BOURDIEU, P. 1962a. Célibat et condition paysanne. Études rurales, v. 5, n. 6, p. 32-136, avr.

1962b. Les relations entre les sexes dans la société paysanne. Les temps modernes, n. 195, p. 307-331, août.

2002. Le bal des célibataires. Crise de la société paysanne en Béarn. Paris : Seuil.

. 2004. The peasant and his body. Ethnography, v. 5, n. 4, p. 579-598, Dec.

HALBWACHS, M. 1955. Esquisse d'une psychologie des classes sociales. Paris : M.
Rivière.

MAUSS, M. 1973. Sociologie et anthropologie. Paris : PUF.

PELOSSE, J.-L. 1956. Contribution à l'étude des usages traditionnels. Revue internationale d'ethnopsychologie normale et pathologique, Tanger, v. I, n. 2, 2ème trimestre.

PULGRAM, E. 1959. Introduction to the Spectography of speech. New York : Mouton.

TROUBETZKOY, N. S. 1964. Principes de phonologie. Paris : Klincksieck. 
THE PEASANT AND HIS BODY

Pierre Bourdieu (Collège de France)

Based on a study of his childhood village of Béarn in southwestern France in the 1960s combining social history, statistics, and ethnography, the author shows how economic and social standing influence the rising rates of bachelorhood in a peasant society based on primogeniture through the mediation of the embodied consciousness that men acquire of this standing. The scene of a local ball on the margins of which bachelors gather serves to highlight and dissect the cultural clash between country and city and the resulting devaluation of the young men from the hamlet as urban categories of judgment penetrate the rural world. Because their upbringing and social position lead them to be sensitive to 'tenue' (appearance, clothing, bearing, conduct) as well as open to the ideals of the town, young women assimilate the cultural patterns issued from the city more quickly than the men, which condemns the latter to be gauged against yardsticks that make them worthless in the eyes of potential marriage partners. As the peasant internalizes in turn the devalued image that others form of him through the prism of urban categories, he comes to perceive his own body as an 'em-peasanted' body, burdened with the traces of the activities and attitudes associated with agricultural life. The wretched consciousness that he gains of his body leads him to break solidarity with it and to adopt an introverted attitude that amplifies the shyness and gaucheness produced by social elations marked by the extreme segregation of the sexes and the repression of the sharing of emotions.

KEYWORDS: bachelorhood; marriage; peasantry; habitus; village culture; gender relations; Béarn; France. 


\section{LE PAYSAN ET SON CORPS}

Pierre Bourdieu (Collège de France)

Appuyé sur un travail sur la ville où il a passé son enfance (Béarn, dans le sud-ouest de la France), effectué dans les années 60 et où il réunit histoire, stastistique et ethnographie, l'auteur explique comment les positions économiques et sociales influent dans la croissance du taux de célibat dans une société paysanne construite sur la primogénuture, grâce à la médiation de la conscience incorporée que les hommes acquièrent de leur position sociale. La scène d'un bal rural où les célibataires forment bande à part permet d'éclairer et de dépouiller le choc culturel entre la campagne et la ville et la dévalorisation des jeunes campagnards qui en découle lorsque les catégories urbaines de jugement pénètrent dans le monde rural. Comme leur éducation et leur position sociale les rendent plus sensibles à la « tenue » (allure, habits, attitude, comportement) et les rapprochent des valeurs urbaines, les jeunes filles retiennent les valeurs culturelles originaires de la ville plus aisément que les jeunes hommes, ce qui oblige ceux-ci à se faire évaluer par des mètres que les dévalorisent aux yeux d'éventuelles conjointes. À son tour, le paysan incorpore l'image sans prestige que les autres, appuyés sur des catégories urbaines, ont de lui. Il commence donc à percevoir son propre corps comme un corps «empaysannés » très marqué d'activités et d'attitudes associées à la vie rurale. La mauvaise conscience qu'il a de son corps l'amène à rompre la communion entre lui et son corps et à adopter une attitude introvertie qui accentue la honte et la maladresse engendrées par des relations sociales imprégnées d'une profonde ségrégation des sexes et du refoulement du partage des émotions.

MOTS-CLÈS : célibat; mariage; paysannerie; habitus; culture locale; relations de genre; Béarn. 